 \\ TREATMENT OF BURNS IN A GENERAL HOSPITAL ${ }^{\dagger}$ \\ B.Sc. (Physiotherapy) (Rand), Onderwysdiploma in Fisioterapie (Pret.)
}

\begin{abstract}
Beskrywing van 'n behandelingstegniek vir pasiënte 'n Beskrwingonde in 'n algemene hospitaal opgeneem "at met brandwok is ontwikkel terwyl die skryfster Eerste "urd. Die tegnie bevel van die Fisioterapie Afdeling van Fintoterapeut in Hospitaal naby Pretoria, was. Nagenoeg (ia Rankuwä̈nte is oor 'n tydperk van 12 maande in die " 1000 pasiënte is oor ' $n$ tydperk vanone 40 -bed sale is hirurgiese sale opgenes en volwasse mans, terwyl die "fgesonder vir kinders enengde" chirurgiese saal behandel is. Die irotle in 'n , gemeng en eenvoudig toe behandelingsme"ikses van tude; met vroee beheer van beta-hemoliktiese streptokok planting; streng beheer van beta-hemoliktiese streptokok il pselldomonas asook die probleme wat ondervind is, word bespreek,

por
\end{abstract}

Ga Rankuwa, destined as the teaching hospital for MEDUNSA, is situated on the border of Bophutatsmed $30 \mathrm{~km}$ north-west of Pretoria. The first wards were waned late in 1973 and I was appointed as Principal phesiotherapist in August 1974. Thus, I was fortunate to see it grow and expand over a period of two and a half years and was able to build up a Physiotherapy Department literally from scratch.

1 would like to concentrate on how we coped with the large number of burn cases. Over a period of twelve months, about one thousand patients were admitted. These patients varied from highly sophisticated urban to primitive rural people, drawn not only from nearby townships, but also from country districts, stretching to Northern and North-Eastern Transvaal. The high incidence of burn trauma could be ascribed to crowded living conditions, the use of cheap heating and cooking methods, such as open fires, paraffin cookers, coke tins, ctc., the inadequate appreciation of the dangers associated with these and poor parental supervision of toddlers and voung children.

At first, these patients were admitted to the general urgical wards. When Dr. Nathan Cirota, who had preious experience of treating burns in a plastic surgery snit, joined the staff, he obtained two forty-bed wards to be used exclusively for the burn cases. Adult males were admitted to one ward and children to the other, as these formed the bulk of the patients, whilst females were treated in a "mixed" surgical ward.

\section{MEDICAL TREATMENT}

Method:

The Israeli method, consisting of early operative treatment with resultant enhanced recovery, was adapted for Ga Rankuwa. Early excision of dead tissue

†Paper presented at Post-registration Course preceding the 12th National Council Meeting of the South African Society of Physiotherapy, May, 1977.

Senior lecturer, Head of Department of Physiotherapy, University of Cape Town. (sloughectomy) was followed by early skingrafting. As there was no means of absolute isolation (such as a special burns unit), a strict but simple nursing technique (closed method) was used routinely. With this treatment routine hospital stay was decreased by $30 \%$ and the complication rate (except for sepsis) was less than $10 \%$.

Probably the most important success factor was teamwork. This involved the surgeon, interns, bacteriologist, haematologist, medical technologist, physiotherapist, dietitian and nursing staff. A comprehensive weekly wardround, with as many members of the team as possible present, was used to review all cases.

\section{Causes:}

The commonest cause of the burn injury was domestic accidents (eight out of ten), followed by assaults, industrial accidents, and suicides; careful history taking of ten gave a strong pointer to the battered baby syndrome.

\section{Degree:}

Two degrees of burning were recognized: superficial, in which only epidermis was involved, hair follicles and sebaceous glands being spared and no skingraft thus being necessary; and deep, in which no skin elements survived and healing was by fibrosis (at the rate of $1 \mathrm{~mm}$ per day), resulting in vulnerable epithelial coverage. For a quick assessment of the degree of burn, Jackson's pain test was used (positive for superficial and negative for deep burns).

\section{Percentage:}

This was calculated according to the rule of fives, which was modified for children and infants. (Fig. 1).

This was revised on the fourth day after admission and then on alternate days when indicated. Some epithelium that seems intact initially may not survive and infection increases the amount of raw epithelium, thus changing a superficial burn to a deep one and/or increasing the extent.

\section{\% ESTIMATION OF BURN AREA}

INFANT

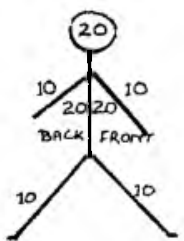

FIGURE 1
CHILD

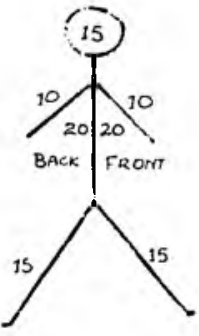

ADULT

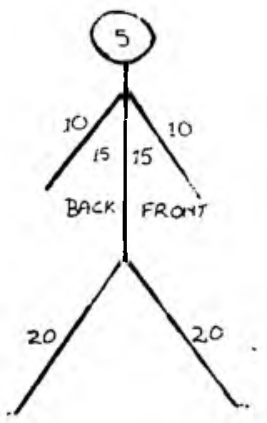


Burn illness:

Shock leads to vasodilatation, increased capillary permeability, increasing fluid loss and hypovolaemia.

Fluid replacement is thus essential in the first 40-50 hours. The amount is calculated using the formula $1,6 \times \%$ burn $\times$ weight in $\mathrm{lb} .=$ number $\mathrm{ml} / 42$ hours. Patients with less than $15 \%$ burns received Ringer's solution or plasma B (low in potassium) as follows: $\frac{1}{3}$ volume in the first 6 hours, $\frac{1}{3}$ volume in the next 12 hours and the last $\frac{1}{3}$ in the next 24 hours. Where the patient had more than $15 \%$ burns, fluid replacement consisted of plasma for the first $\frac{2}{3}$ and of whole blood for the last $\frac{1}{3}$. The haemoglobin level was assessed on admission and thereafter at weekly intervals, as anaemia has an adverse effect on healing and skin graft taking. Wound swabs were cultured weekly and all grew some pathogens. Beta haemolytic streptococcal infection was treated with local antibiotics (laboratory and sensitivity tested) because it caused breakdown of recent granulations and skin grafts. Pseudomonas infection was also treated because of the danger of pseudomonas septicaemia. A temperature spike above $38^{\circ} \mathrm{C}$. was considered an index of potential septicaemia and treated prophylactically by gentamycin, treatment being altered only when a blood culture was available. Excessive catabolism was prevented or controlled by means of a high protein, high calorie diet, rich in vitamin $\mathrm{C}$ and ferrous sulphate, in order to promote tissue regeneration.

\begin{abstract}
Admission:
All patients with burns of $10 \%$ or more, as well as those with burns involving the face, hands, perineum or joints, were admitted. A standard admission chart was filled in, giving basic data such as weight, age, percentage burn, estimation of the depth of burn, type of burning agent, adequacy of airway, type of analgesia given, etc. Standardised treatment such as fluid replacement, emergency blood investigations, indwelling catheter ( $20 \%$ burn and over), prophylactic anti-tetanus injection, wound swabs, dressings (open or closed) or splintage of joints had to be recorded. Further treatment such as change of dressings (for reassessment), operations, physiotherapy requested, complications, or progress were noted on the same chart.
\end{abstract}

\section{Closed method:}

This technique was used because of the large number of patients and the ward architecture. A dilute solution of chlorhexidine or eusol was made up daily and used to clean the burns. Necrotic tissue was removed, but blisters were not punctured, as this increased the risk of infection. Tulle gras was placed on the burns, then layers of gauze soaked in one of the above-mentioned solutions; this was covered with crêpe bandage, and splinting was applied where indicated and secured with further crêpe bandage. The first dressing was removed after four days, the percentage and depth of burn reassessed and thereafter daily dressings were done.

\section{Infection:}

This usually started locally, with a strong tendency to systematic spread. Weekly swabs were sent for culture and sensitivity tests. The technologists made use of an accelerated process so that results were available within a few hours (usually the next day). Local application of antibiotics was used, because the decreased vascularity in burn wounds was thought to render the effectiveness of systemic antibiotics questionable. Burn creams were not used, as these masked the state of the burns.
Surgery:

A healthy base, viz. optimal nutrition, granulation, haemoglobin concentration and oxygenation, can be maintained for 3-4 weeks. Thus, sloughectomy and skin. grafting, when indicated, should ideally be done within twenty-one days of sustaining burn trauma, so as to take advantage of the optimum base. Partial thickness grafts were used because these take better; however, they give a poorer cosmetic result than full thickness grafts, which were used on the face and neck. Where large areas had to be covered and only small donor sites were available, either a mesh dermatome was used or strips of skin were laid on at right-angles to the line of stress, movement or pull of underlying tissue. Plaster of Paris splints were applied in theatre af ter the dressings if joints were involved in the burn. The graft was inspected for viability after five days and immobilised for a further five days if it had taken. If sloughectomy proved necessary (usually Aserbine dressings were tried first), skingrafting was done immediately afterwards. If bleeding was excessive, grafting was delayed for four days. $\ln$ suitable cases, donor skin was stored at $5^{\circ} \mathrm{C}$. and applied in the ward under local anaesthesia.

\section{PHYSIOTHERAPY}

The following is the ideal physiotherapy treatment as one would like to see it, but obviously is not always possible. All patients, except those with more than $35 \%$ burns or where the face, neck or genitalia were involved, were started on full physiotherapy as soon as possible after admission.

\section{First four days:}

The burns were covered by dressings, splints were applied to joints involved in the burn and the patient was put on a drip if the burn was over 15\%; an indwelling catheter was used if it was over $20 \%$. The length and frequency and often time of treatment depended very much on the patient's general condition, the depth of sedation, level of consciousness and when sedation was given. Treatment was fitted in with ward routine so as to cause as little disturbance of the patient as possible.

Breathing exercises were done routinely where burns involved face, neck and large areas of the trunk, and where patients were extensively burnt. Movements aimed at obtaining full ROM (range of movement); thus splints were removed for treatment and replaced immediately afterwards. Each joint involved in the burn was put through a full ROM for each movement at least once a day. At first this was often assisted active or passive movement. Accessory movements were used where indicated (for example, of fingers). All joints not directly involved in the burn were moved actively where possible, otherwise passively. The movements were repeated up to five times each twice a day, preferably $\frac{1}{2}$ to 1 hour after routine sedation and/or analgesia.

\section{Assessment:}

ROM was accurately recorded by means of a goniometer and where possible muscle strength assessed according to the Oxford scale. Any abnormality, such as existing deformity, contracture, or abnormal tone, was noted (a fair number of epileptics with neurological symptoms, patients with cerebro-vascular disorder and some with a congenital deformity were among those admitted). The patient's general state, degree of cooperation, functional independence, etc., were noted.

\section{After four days:}

Bandages were removed, and the percentage and depth of burn were reassessed; thereafter dressings were done daily. Movements were then carried out when the burns were exposed and again once dressings had been reapplied. Whilst the burns were exposed, greater ROM 
could be obtained, but the burnt area became dry and more painful and was difficult to handle. A layer of tulle gras was left on the burn to ease this problem. After dressings had been done, all patients that were ambulant or could tolerate transport in a wheelchair were taken to the department for individual exercises and self-exercise, using apparatus, to build up strength and endurance. Class-work was done successfully with male adults and children. Some women also became interested and joined the class. These classes enabled us to cope with a large number of patients and the patients seemed to enjoy the competition and companionship.

\section{Surgery:}

If contractures developed or were present on admission (old cases from outlying hospitals), surgical release was done within 14-21 days when response to physiotherapy was unsatisfactory. After sloughectomy, gentle exercises (to prevent further haemorrhage) were permitted. After skingraft, no movement of the graft was permitted for ten days. If the graft had not taken after five days, hysiotherapy could begin again. Patients with extensive furns still had exercises to maintain function and mobility of areas not involved in skingrafting.

\section{Splinting:}

This was applied on admission or in theatre after surgery. POP (Plaster of Paris) was used. Splints were renewed or strengthened by the physiotherapist, as indicated. Shoulders were splinted in full elevation if the axilla was involved; and elbows in extension; wrists and hands were placed in the functional position (wrist in $30^{\circ}$ dorsiflexion, thumb in full abduction, metacarpophalangeal and inter-phalangeal joints in $30^{\circ}$ flexion); the neck was put in a collar to maintain extension; hips and knees were extended to $180^{\circ}$; and ankles in midposition.

\section{Scarring:}

Hypertrophic scarring in this series developed mainly on the neck and face. Apart from the splinting (with pressure), ultrasound therapy, sometimes combined with icepacks and always followed by massage with lanolin, was used to treat hypertrophic scars. Daily doses of ultrasound $\left(1-1.5 \mathrm{~W} / \mathrm{cm}^{2}\right)$ were given, time depending on the extent of the area involved. Ultrasound was also used to soften contractures, to prevent puckering of skingrafts and to mobilise hands and fingers.

\section{IROBLEMS}

The sheer bulk of patients and limited number of physiotherapists precluded ideal treatment and it was found to be impractical to do weekly accurate assessments of movement by means of a goniometer.

2. As routine week-end work was impossible, mainly owing to the geographical situation of the hospital, lack of physiotherapists and small numbers of emergencies (for which I was usually called out) patients did regress over week-ends.

3. The nursing staff had a tremendous load with the number of dressings to be done. They changed every month and it took a while to retrain each new set, even if the sister in charge did not change.

4. The medical interns also rotated every four weeks, and at nights and week-ends patients were admitted by the medical officer covering all surgical services and were thus not always treated according to the standard technique.

5. Adult females were in a "mixed" surgical ward and the technique was never adhered to as strictly as in the other wards.

b. During the winter months, admission rates were very high and the paediatric ward in particular suffered from overcrowding with a resultant increase in cross-infection.

\section{CONCLUSION}

Despite the problems mentioned above, results were still encouraging and the system thought worthwhile. The main factors in determining the success seemed to be:

1. An enthusiastic surgeon who insisted on meticulous observance of technique.

2. High quality nursing.

3. Liaison and teamwork in all respects from all members concerned.

Acknowledgements:

My thanks to Dr. N. Gilliland, Superintendent of $\mathrm{Ga}$ Rankuwa, for permission to print the article. Also to Dr. Cirota for his help and encouragement. A particular word of thanks to physiotherapy staff and students at $\mathrm{Ga}$ Rankuwa who treated the patients.

\section{SPECIAL INTEREST GROUPS}

\author{
South African Society of Physiotherapy
}

Obstetric Association of S.A.S.P.:

Secretary: Mrs. B. Kastell,

11 Bath Avenue,

Parkwood,

Johannesburg,

2193.

Tel.: $42-7410$.

Manipulative Therapists Group of S.A.S.P.:

Secretary: Miss C. de Smidt,

Erin Villa,

5 Lower Trill Road,

Observatory,

7925.

National Hospital Group of S.A.S.P.:

Secretary: Miss P. Bowerbank,

P.O. Box 28697,

Sunnyside,

Pretoria,

0132.

Private Practitioners' Association of S.A.S.P.:

Secretary: Mrs. A. Miot,

P.O. Box 6681,

Johannesburg.

Phone 784-3328.

Lecturers Group of S.A.S.P.:

Secretary: Miss S. Irwin-Carruthers, Physiotherapy Department, P.O. Box 63, Tygerberg, 7505 .

S.A. Neurodevelopmental Therapy Association:

Secretary: Mrs. L. Freeling,

P.O. Box 792,

Krugersdorp,

1740 . 